Бойко-Гагарін Андрій,

кандидат історичних наук, завідувач сектору проблем фондової роботи boiko.gagarin@gmail.com http://orcid.org/0000-0003-4610-3665 Національний музей історії України, вул. Володимирська, 2, м. Київ, Україна, 01001

\section{Boiko-Gagarin Andriy,}

Candidate of Historical Science, head of the sector of the treasury problems

boiko.gagarin@gmail.com

http://orcid.org/0000-0003-4610-3665

National Museum of History of Ukraine,

2, Volodymyrska str., Kyiv,

Ukraine, 01001

\title{
НОВІ ДАНІ ПРО ВВЕЗЕННЯ ДО РОСІЙСЬКОЇ ІМПЕРІЇ ФАЛЬШИВИХ ГРОШЕЙ ІЗ АНГЛІЇ ПРОТЯГОМ ХІХ СТ.
}

У першій чверті XIX cm. збільшення кількості виявлених підроблених кредитних білетів, завезених до Російської імперії із Англї̈, серйозно стурбувало владу. Слідство поступово набуло рівня державного значення. У 1820-х рр. російська влада вдалась до ретельного відслідковування всіх євреїв, що прямували до Царства Польського $i$ потенційно могли мати при собі фальшиві кредитні білети, призначені для збуту у Росії.

Спроби провезення т.зв. «англійських» підробок до Польщі зафіксовано також через кордон із Пруссією, що змусило владу до перевірки євреїв, виїжджаючих до Пруссії, підозрюючи, щчо через неможливість отримання ними паспортів до Англії, щуо підлягало ретельному контролю, поява таких громадян з високим ступенем імовірності супроводжувалась наявністю в них підроблених прусських документів.

28 жовтня 1868 р. до Варшавського губернатора надсилається рапорт начальника Радзеювського уїзду про наявні достовірні свідчення про збувальника фабрикованих у Лондоні ще 1864 р. фальшиві російські кредитні білети 10 руб. номіналу уродженщем Польщі, власником маєтку у м. Ольганово Влоилавського уїзду Варшавської губ. - Адамом Богушем, щзо збував їх у прусській провіниій - Великому князівстві Познанському торгівцям крупною рогатою худобою та овещь. 11 січня 1870 р. Варшавський карний суд виніс вирок збувальнику фальшивих банкнот Адаму Богушу - позбавленням всім прав та свобод та засланням до Сибіру на 6 років каторжних робіт. Та він був не єдиним, чия справа відрізнялась гучністю у розслідуванні фінансової диверсії з Лондону, в той самий час все більших обертів набирає справа іншого англійського агента збувальника - Леона Варненке.

Інформація про фальшивомонетника набула такого розголосу та чутки про наповнення начебто всієї Росії фальшивими англійськими банкнотами так сильно укорінились в уяві населення, що породили новий вид шахрайства - пропозиції купівлі якісних «англійських» підробок для легкого збуту.

Ключові слова: Російська імперія, Англія, фальшування грошей, архівні матеріали, музейні колекції.

\section{THE NEW DATA ON THE IMPLEMENTATION OF THE COUNTERFEIT MONEY FROM ENGLAND TO THE RUSSIAN EMPIRE IN THE XIX CENTURY}

In the first quarter of the nineteenth century the increase in the number of detected counterfeit credit bills brought to the Russian Empire from England has seriously alarmed the authorities. The investigation has gradually gained a national level of importance. In the 1820s, the Russian authorities resorted to careful tracking of all Jews who went to the Kingdom of Poland and could potentially carry counterfeit credit bills for sale in Russia. 
Attempts to transport so-called «English» counterfeiting in Poland was also recorded across the border with Prussia, forcing authorities to check Jews leaving for Prussia, suspecting that because of their inability to obtain passports to England, the subject of careful control, the appearance of such citizens with a high degree of authority and trust them fake Prussian documents.

In October 28, 1868 the Governor of Warsaw has reached the report of the Chief of the Radzewski County on available credible records of a salesman fabricated in London as early as 1864 fake Russian 10 rubles credit bills by a Polish-born owner of an estate in Olganowo, Wtoclaw County of Warsaw - Adam Bogusz, who was selling them in the Prussian province - the Grand Duchy of Poznan to the sheep traders. On January 11, 1870, the Warsaw Penitentiary Court sentenced the seller of the counterfeit banknotes to Adam Bogusz - deprivation of all rights and freedoms and exile to Siberia for 6 years of hard labor. But he was not the only one whose case was notorious for investigating a financial diversion from London, while at the same time, another English agent, the salesman, Leon Varnenke, was gaining momentum.

Information about counterfeiters has gained such publicity and rumors about the stuffing of counterfeit banknotes from England throughout the Russian Empire have become so entrenched in the imagination of the population that they have spawned a new kind of fraud offers to buy high-quality "English »Counterfeits for easy sale.

Key words: Russian Empire, England, money forging, archive materials, museum collections.

Проблеми історії грошового обігу в Наддніпрянській Україні в XIX ст. є частиною історії фінансової політики уряду Російської імперії [22] і тісно пов'язані із з усіма іншими ії складовими та має певну специфіку методології дослідження $[11 ; 12 ; 14 ; 15 ; 16$; 17]. Практика фінансових диверсій з метою підриву економіки ворогуючої країни з боку іноземних держав відома із глибокої давнини. Зазвичай такі серйозні економічні диверсії відбуваються у випадках війни чи серйозного політичного протистояння між країнами, коли ввезення на територію супротивника фальшивих грошей за зразком введених в обіг державних переслідує деструктивну мету для економіки. Так, зокрема, проти Російської імперії здійснювали фінансові диверсії у 1812 р. з боку Франції [13; 33], а також у роки Першої Світової війни з боку Австро-Угорщини та Німеччини [18-21].

Протягом XIX ст. на території Російської імперії почастішали випадки виявлення фальшивих кредитних білетів, а згодом було встановлено, що країною їх походження $\epsilon$ Англія, а самі фальсифікати виготовляються на професійно обладнаній всім необхідним устаткуванням фабриці у Лондоні. Досліджуючи матеріали державних історичних архівів, нам вдалось встановити, що збут підробок із Лондона проводився із першочерговим ввезенням їх на територію Царства Польського, нерідко причетним до цього процесу ставали польські націоналісти, що боролись проти російського царату. У статті вводяться в науковий обіг архівні матеріали, що висвітлено у науковій історіографії вперше.

Метою статті $є$ введення в науковий обіг та аналіз нових даних щодо ввезення до Російської імперії підробок грошей із Лондона протягом XIX ст., що виявлено за матеріалами державних історичних архівів та газет.

Найвище ухвалене «Укладення про покарання карні та виправні», затверджене імператором 15 серпня 1845 р. за № 19283 [2, с. 236-237], встановлювало, що за ввезення виготовленої за кордоном російської фальшивої монети, винні підлягають аналогічному покаранню, що i виробники фальшивої російської монети всередині імперії, тобто підлягають покаранню у вигляді позбавлення всіх прав майнових та висилці на каторгу у фортеці на термін від 8 до 10 років, а якщо вони згідно із законом не позбавлені тілесних покарань, то покарати батогом катами.

У першій чверті XIX ст. збільшення кількості виявлених підроблених кредитних білетів, завезених до Російської імперії із Англії, серйозно стурбувало владу. Слідство поступово набуло рівня державного значення. У 1820-х рр. російська влада вдалась до 
ретельного відслідковування всіх євреїв, що прямували до Царства Польського i потенційно могли мати при собі фальшиві кредитні білети, призначені для збуту в Росії.

У липні 1825 р. на кордоні до Польського Царства було затримано прусського єврея, уродженця м. Мемеля (нині м. Клайпеда у Литві - Б.Г.) - Хель Ланца (або Йохель Ланца), що прямував з Англії (де на той момент він вже проживав близько 20 років), який займався обміном асигнацій на срібні та золоті монети, а при перетині кордону в якого виявлено фальшиві російські кредитні білети та монети, карбовані для Польщі [29, с. 1416].

Спроби провезення т.зв. «англійських» підробок до Польщі зафіксовано також через кордон із Пруссією, що змусило владу до перевірки євреїв, виїжджаючих до Пруссії, підозрюючи, що через неможливість отримання ними паспортів до Англії, що підлягало ретельному контролю, поява таких громадян 3 високим ступенем імовірності супроводжувалась наявністю у них підроблених прусських документів [30, с. 95]. Розслідування справ фальшивомонетників та розшук кур'єрів із завезення до Росії фальшивих кредитних білетів вівся спільно із підтримкою уряду Пруссії. Цікавий факт в цьому відношенні стався 16 липня 1829 р. - підозра на провезення фальсифікатів пала на єврея Абрахама Іракла, розслідування велося за кошти прусського уряду, що пізніше повністю компенсувалось російським урядом, що розраховував стягнути видатки на проведення суду та слідства із винного [30, с. 105].

Слідчі дії та пошуки перевізників підробок не завжди супроводжувались успіхом, так запідозрений єврей Март Шек, арештований 29 липня 1829 р., був виправданий і звільнений через відсутність доказів про причетність його до фальшування монет $\mathrm{i}$ завезення підробок [30, с. 114]. Поліція шукала зв'язки між вже затриманими фальшивомонетниками і тими, хто підпадав під підозру у завезенні фальсифікатів із Англії. Так 18 травня 1830 р. під підозру потрапив єврей Лейзер Гебід, що повернувся із Англії та, імовірно, міг мати контакт із вже викритим та розшукуваним фальшивомонетником Лейзеровичем, що міг маскуватись під різноманітними прізвищами [30, c. 149].

Перевірці підлягали також і інші російські громадяни, що прямували із Англії у інші регіони. Так Управління Варшавського губернатора повідомляє до KRSW про реєстрацію Генеральним консульством Російської імперії у Лондоні паспорту сину одеського купця III-ї гільдії єврею Емасу Бернштейну, виданого йому одеським очільником міста 23 червня 1836 р. під № 5244, а також те, що Е. Бернштейн повертається в Одесу із імовірністю може мати фальшиві кредитні білети [31, с. 283-284 odw.]. У січні 1857 р. начальником одеського митного округу було запідозрено, що на очікуваному у порт судні «William Wheattey» двоє євреїв намагатимуться привезти «англійських» підробок на загальну суму близько 1 млн. руб. сріблом, захованих у замовленій ними машині для прання білизни [3, c. 1-1 зв.]. У 1857 р. в Одесі до генерал губернатора надійшли свідчення також про доставлення англійцями фальшивих грошей до Криму [7, арк. 7].

14 серпня 1858 р. у Острозі було спіймано шотландського підданого Йогана Шмідта (або Сміта), що назвав себе уродженцем Варшави Йосифом Яковлєвим Аварським, проти якого надав свідчення ув'язнений за збут підроблених банкнот арештант острозького тюремного замку Михаїл Кац, який нібито дізнався під час перебування їх у тюрмі було висловлене бажання Й. Шмідтом розповсюджувати фальшиві гроші [8, арк. 19].

22 вересня 1865 р. в канцелярію Київського військового, Подільського та Волинського генерал-губернатора надійшли секретні свідчення про те, що членами Польського революційного комітету готується ввезення із Лондону до Галичини для збуту російських кредитних білетів на суму 45000 руб. [27, арк. 1-1 зв.].

30 серпня 1867 р. міського голову Одеси повідомлено секретною запискою 3 управління Новоросійського та Бессарабського генерал губернатора про підозру шотландського лорда Девсена, що проживає в Лондоні у організації ввезення до Одеси та Харкова через турецькі Галац та Константинополь підробок російських кредитних білетів 
[4, арк. 1-1 зв.]. 31 серпня 1867 р. підозра у завезення «англійських» підробок випала на єврея, громадянина Туреччини - Марка Мошковича, який також представлявся Мордохом, що міг імовірно прибути до міста на теплоході «Люцифер» [5, арк. 3 зв.].

На початку червня 1868 р. у Константинополі затримано російського підданого, уродженця Гродненської губ., Янкеля Фрідмана, підозрюваного у виготовленні фальшивих асигнацій та доставлено у Генеральне консульство Російської імперії [6, арк. 1-2 зв.]. 28 жовтня 1868 р. до Варшавського губернатора надсилається рапорт начальника Радзеювського уїзду (нині м. Радзеюв у складі Куявсько-Поморського воєводства Польщі - Б.Г.) про наявні достовірні свідчення про збувальника фабрикованих у Лондоні ще 1864 р. фальшиві російські кредитні білети 10 руб. номіналу уродженцем Польщі, власником маєтку у м. Ольганово Влоцлавського уїзду Варшавської губ. Адамом Богушем, що збував їх у прусській провінцій - Великому князівстві Познанському торгівцям крупною рогатою худобою та овець [32, str. 1-2]. Частину фальшивих грошей у сумі 400 руб. Адам Богуш відправив поштою до мешканця м. Шпиталь-Дольний Варшавської губ. - прусському підданому Генріху Вундшу, в якого під час обшуку жандармами земської стражі було виявлено фальшивий 10 руб. кредитній білет із № 1,502,652 зразка 1864 р. та ще 5 листів із подібним вмістом, після чого його було заарештовано та поміщено до Брест-Куявської (або Бжесць-Куявської) тюрми [32, str. 5]. 22 листопада 1868 р. на користь Генріха Вундша - годувальника сім’ї із 10 дітей буде особисто клопотати та запевняти в доброчесності бувший військовий начальник м. Влоцлавек - князь Вітгенштейн, запевняючи, що той не мав злочинних намірів, ведучи листування із Адамом Богушем [32, str. 12]. На допиті Вундш зізнався, що будучи у Торуні, виміняв у Адама Богуша прусські талери на російські рублі, але ті були справжніми та про можливу підміну він гадки не мав, після чого був відпущений із тюрми із повинністю бути невиїзним до кінця терміну слідства [32, str. 57-58]. За сприяння прусської влади проведено обшук у деякого фон-Мікта, в якого виявлено 3400 подібних фальшивих 10 руб. банкнот, також отриманих від Адама Богуша, якого було вже затримано і доставлено до тюрми у м. Іновроцлав. Остерігаючись виправдання Адама Богуша у судах Пруссії, російська влада вимагає видати його та помістити у цитадель у м. Александрув Куявський, куди також доставити підозрюваного у допомозі Богушу по збуту підробок арештованого Генріха Вундша, після чого етапувати обох під суворим караулом до Варшави [32, str. 16, 20]. Але видача до Польщі арештованого Адама Богуша супроводжувалась низкою складнощів - у кінці року грошей на транспортування та утримання в'язня (визначених у сумі 200 руб.) не вистачало, а також у м. Радзеюв не було придатного приміщення для його утримання 3 караулом, через що прикордонним комісаром і начальником Радзеювського уїзду полковником Густавом Берхманом було запропоновано відправити Адама Богуша у Торунь, звідки доставити на пряму у Варшаву до Олександрівської цитаделі [32, str. 27-28]. Справа вимагала якнайскорішого вирішення з екстрадиції Богуша, адже для уникнення суду в Російській імперії, його родина вимагала розгляду його справи у Бромбергському апеляційному суді, адже злочин здійснено у землях Пруссії [32, str. 29]. У той час у Влоцлавеку затриманий інший спільник Адама Богуша - утримувач маєтку його дітей в Ольганово - Валентій Вієвіоровський, що намагався збути отримані від Богуша фальсифікати, та будучи арештованим, пропонував у заставу за своє звільнення наявні на його рахунку 2000 прусських талерів, арештованих в подальшому Казною 3 отриманням нею депозитної першості на отримання грошей арештованого [32, str. 73].

21 листопада 1868 р. начальник Радзеювського уїзду Густав Берхман повідомляє Варшавського губернатора про виявлення у підданих Пруссії Павла Брузді та його зятя Мартина Меха сім сумнівних кредитних білетів 10 руб. номіналу, які ті отримали за продані вівці, з високим ступенем імовірності будучи у змові із Адамом Богушем у поширенні підробок [32, str. 38]. В той час брат Адама Богуша - Август намагається 
продати родинний маєток в м. Ольганово для спроби викупити брата під заставу [32, str. 53 odw.].

У той же час у процесі намагань російської влади добитись екстрадиції Богуша до Царства Польського у Торуні місцевим прокурором Г. Лоссовським виявлено наміри коханки відомого польського уродженця Раймунда Янковського - Матільдою Френдерейх спільно із банкіром Сімонсоном організувати доставку 3 Англії великої кількості фальшивих 50 руб. асигнацій, які б Сімонсон міг збувати, маючи значні торгівельні обороти із місцевими купцями. Підробки Матільда Френдерейх планувала отримувати за допомогою польських емігрантів у Лондоні, Парижі, а також із Швейцарії. Зусиллями прокурора Торуні зловмисницю було заарештовано та поміщено у тюрму замку у м. Грудзьондз. В цьому всьому вдалось особисто пересвідчитись начальнику Радзеювського уїзду - Густаву Берхману, який враховуючи значну турботу прокурорів Торуні та Іновроцлава перед Російською владою, клопотав про представлення їх до нагород російськими орденами Св. Станіслава II ступеня [32, str. 94].

У лютому 1869 р. рішенням Бромбергського апеляційного суду Адам Богуш разом із 64 підробленими банкнотами i власними записами у зошитах був доставлений залізничним транспортом у Варшаву, де був зустрітий місцевими жандармами i поміщений в Олександрівську цитадель. Завданням слідчих було встановити, чи причетний Адам Богуш до запідозреного у виробництві у Лондоні підробок - уродженця Калішської губ. - Полюшковича, що був затриманий прусською владою із привезеними із Лондона у прусське м. Бреслау все необхідне обладнання, яким згідно поширених чуток, він наче вже виготовив підробок більше 1 млн. [32, str. 108] 3 травня 1869 р. до варшавської слідчої тюрми направляють із Влоцлавека і Валентина Вієвіоровського [32, str. 152].

Начальником Радзеювського уїзду Густавом Брехманом було також подано до Міністерства внутрішніх справ рапорт з проханням компенсувати понесені ним витрати під час розслідування та переміщення Адама Богуша, адже з витрачених ним 170 руб. 3 коп., лише 100 руб. були раніше виділені йому з канцелярії Варшавського губернатора [32, str. 133-134]. 11 січня 1870 р. Варшавський карний суд виніс вирок збувальнику фальшивих банкнот Адаму Богушу - позбавленням всім прав та свобод та засланням до Сибіру на 6 років каторжних робіт.

Так закінчилась справа Адама Богуша - головного організатора збуту «англійських» підробок російських кредитних білетів у Царстві Польському. Та він був не єдиним, чия справа відрізнялась гучністю у розслідуванні фінансової диверсії з Лондону, в той самий час все більших обертів набирає справа іншого англійського агента збувальника - Леона Варненке.

На початку 1990-х рр. при знесенні будинку будівельниками був виявлений архів, що належав члену Британського Королівського товариства фотографів - Леону Варненке. Численна кількість наявних у скрині листів, квитанцій, фото, записників та банкнот було продано на аукціонах «Philips» у 1991 році та наявні у архіві банкноти - на аукціоні «Spink» у 2008 р. Науковий аналіз документів і банкнот дозволив встановити пряму причетність справи до політичного протистояння Російської та Британської імперії у XIX ст. [23, с. 83-84].

Виявлені в Лондоні документи дозволили встановити, що головним організатором фінансової диверсії став Леон Варненке - колишній учасник Польського повстання 1863 р., що втік із Російської імперії, де був відомий як Владислав Малаховський, розшукуваний російською владою за винагороду у 10 тис. руб. Через деякий час у Лондоні громадянином Австро-Угорщини - Леоном Варненке було відкрито фірму «Варненке і Ко». Успішний розвиток підприємства дозволив невдовзі відкрити філії компанії Леона Варненке у Парижі, Брюсселі, Петербурзі та Москві. Нове життя колишній втікач «Леон Вікентійович Варненке» продовжив як успішний підприємець, а також винахідник у фототехніці, друкувався у наукових журналах. Але втілені в життя новітні 
технології не отримали фактичної підтримки споживачів, поступово фінансовий стан підприємств Леона Варненке став погіршуватись. 31865 по 1900 р. Л. Варненке доповнив до родів своєї діяльності також і підробку російських кредитних білетів, створивши таємну організацію, куди входили польські та російські емігранти, а також піддані Британії. Втілення фото технологій у процес виготовлення фальшивих кредитних білетів забезпечив успіх у їх збуті та проблематичному виявленні навіть професійними касирами в Російській імперії. Безумовним доказом фальшування саме Леоном Варненке російських кредитних білетів слугують наявні у виявленій скрині кліше для друку грошей, а також різноманітні фото приладдя. Затримання Леона Варненке із готовою продукцією фальсифікатів відбулось 27 січня 1899 р. у Франції - в м. Кале. На прохання російського посольства у Лондоні, поліцією було проведено обшук, що підтвердив той факт, що у будинку відбувався процес фальсифікації грошей. Виявлені у будинку листи англійською, французькою, німецькою та російською мовою дали можливість висловити припущення про причетність до таємного виробництва Варненке фальшивих кредитних білетів за дорученням англійської влади, що, звісно ж, офіційно не набуло підтвердження, докази співпраці фальшивомонетника фотографа-винахідника Леона Варненке із британськими спецслужбами не було підтверджено чи доведено. Відповідно до ст. 133 Кримінального Кодексу Французької республіки, винного у збуті фальшивих грошей МалаховськогоВарненке суд у Екс-ан-Провансі виніс вирок у два роки тюремного ув'язнення та 100 франками штрафу - 14 листопада 1899 р. засудженого зобов'язали покинути територію Франції, повідомивши тюремне керівництво Швейцарії про направлення його туди, після чого сліди Малаховського-Варненке втрачаються. У жовтні 1900 p. дружина фальшивомонетника - Марія Варненке офіційно повідомляє про смерть свого чоловіка у Швейцарії [23, с. 86-88].

Таким чином, спираючись на матеріали із лондонської скрині, О. Парамонов описав процес зародження справи однієї із найбільших фінансових афер XIX ст. Продовження справи Л. Варненке полягає у виявленні та розшуку його в самій Російській імперії, свідчення про що зберігаються сьогодні в архівах та матеріалах газетної періодики в Україні.

Інформація про фальшивомонетника набула такого розголосу та чутки про наповнення начебто всієї Росії фальшивими англійськими банкнотами так сильно укорінились в уяві населення, що породили новий вид шахрайства - пропозиції купівлі якісних «англійських» підробок для легкого збуту. Саме таку пропозицію надавали євреї у Вільні, пропонуючи підробки по ціні 10\% номінальної вартості, видаючи довірливим потенційним аферистам пачки кольорового паперу, лише зверху та знизу маючи справжні гроші, щоб зімітувати партію підробок [1, с. 381].

16 лютого 1883 р. у Варшаві за повідомленням газети «Киевлянин» в касі театру «Розмаїтість» було затримано двох євреїв, які по черзі намагались придбати театральні квитки за фальшиві 3 руб. кредитні білети, розпізнані жандармом. Після обшуку та виявлення інших підробок у помешканні одного із затриманих, той зізнався, що отримує фальсифікати із Лондона [25, с. 2].

27 травня 1911 р. Київським губернатором О.Ф. Гірсом надсилається секретний циркуляр до керівників поліції Київської губ. щодо наявної інформації про наміри ввезення у вересні цього року з Англії до Росії фальшивих 3 руб. кредитних білетів на суму 5 млн. руб. для збуту їх серед робітничих та малозабезпечених громадян в оплату найманої праці [28], відповідно до чого наказано Київському i Бердичівському поліцмейстерам застосувати заходи 3 попередження проникнення підробок у країну, перевіряючи громадян, шо повертатимуться у вересні із закордонних подорожей [26, арк. 76].

30 листопада та 1 грудня 1896 р. газета «Діло» інформує населення про появу у Тернополі великої кількості фальшивих грошей, що вже виявлені і досліджуються представниками місцевої влади. Підозра у виготовленні підробок припадає на різьбярів 
Угера Басса, Лейбу Галлера та Хаскля Зайда [24, с. 3], висловлюється підозра про збув ними підробок, виготовлених у Англії: «Багато підроблених банкнот пущено у обіг у Тернополі. Шість того роду фальсифікатів знаходяться вже у руках влади. Підозрюваних у веденні торгівлі фальшивими банкнотами Ушера Басса, Лейбу Гелера та Хаскля Зайда доставлено до суду. Фальсифікати мають походити із Англії» [10, с. 2].

На території Російської імперії відомі відгуки і не лише англійських фальсифікатів російських кредитних білетів, а і також англійських фунтів. У матеріалах канцелярії Вітебського громадянського губернатора I. Колобовою виявлені свідчення про затримання у м. Кельн 28 серпня 1868 р. уродженця м. Невеля - Андрія Сршова з виготовленими у Лондоні фальшивими 20 фунтовими банкнотами [9, s. 193].

Із збільшенням кількості виявлених фальсифікатів російських кредитних білетів, починаючи із першої чверті XIX ст., слідством було встановлено факт завезення підробок iз Англії, де якісно обладнана фабрика із виготовлення фальсифікатів російських кредитних білетів була організована в Лондоні. У 1820-х рр. російська влада вдалась до ретельного відслідковування всіх євреїв, що прямували до Царства Польського i потенційно могли мати при собі фальшиві кредитні білети, призначені для збуту у Росії. Спроби провезення т.зв. «англійських» підробок до Польщі зафіксовано також через кордон із Пруссією.

У другій половині XIX століття у процесі ввезення підробок із Англії особливо виділився величезними обсягами вввезених до Росії підробок Леон Варненке. Засуджений за ввезення до Царства Польського з метою збуту в інших регіонах Російської імперії польський єврей Адам Богуш яскраво продемонстрував прагнення польських націоналістів до деструктивних дій у боротьбі іх з російським царатом.

Інформація про фальшивомонетника набула такого розголосу та чутки про наповнення начебто всієї Росії фальшивими англійськими банкнотами, так сильно укорінились в уяві населення, що породила новий вид шахрайства - пропозиції купівлі якісних «англійських» підробок для легкого збуту.

\section{ДЖЕРЕЛА ТА ЛІТЕРАТУРА}

1. Вильне придуман новый род промысла // Николаевский Вестник. № 93. 3 декабря. Николаев, 1893. С. 381.

2. Деммени М. М. Сборник указов по монетному и медальному делу в России, помещенных в Полном Собрании Законов с 1649 по 1881 г. Выпуск 3. Санкт-Петербург: Издание Вел. Кн. Георгия Михайловича, 1887. С. 236-237.

3. Державний архів Одеської області (ДАОО). Фонд 1. Управління Новоросійського та Бессарабського Генерал Губернатора. Опис 203. Справа 1. По відношенню Начальника Одеського митного округу, нібито в привезеній із Лондона в Одесу машині, що належить євреям Ієхудок Доб Зейдлю та Якову Лейбу Лівщицу, приховані фальшиві російські кредитні білети. Рік 1857. Арк. 1-1 зв.

4. Державний архів Одеської області (ДАОО). Фонд 2. Канцелярія одеського градончальника. Опис 2. Справа 1111. Про спостереження над ввезенням у Росію фальшивих кредитних білетів. Рік 1867. Арк. 1-1 зв.

5. Державний архів Одеської області (ДАОО). Фонд 2. Канцелярія одеського градончальника. Опис 2. Справа 1109. Про спостереження за турецько-підданим євреєм Марко (він же Мордхай) Мошковичем, підозрюваному у торгівлі фальшивими кредитними білетами, який для цих цілей прибуває в Одесу. Рік 1867. Арк. 3 зв.

6. Державний архів Одеської області (ДАОО). Фонд 2. Канцелярія одеського градончальника. Опис 2. Справа 1207. По відношенню Російського генерального консула у Константинополі, при якому присланий в Одесу єврей Янкель Фрідман, підозрюваний у збуті фальшивих російських кредитних білетів і різних облігацій інших держав. Рік 1868. Арк. 1-2 зв. 
7. Державний архів Одеської області (ДАОО). Фонд 361. Одеський попечительський про тюрми комітет. Опис 1. Справа 229. Про фальшиві кредитні білети. Рік 1854. Арк. 7.

8. Державний архів Тернопільської області (ДАТО). Фонд 132. Кременецький уїзний суд. Опис 2. Справа 684. Справа про звинувачення англійського підданого Шмідта у підробці грошових знаків. Рік 1858. Арк. 19.

9. Колобова И. Н. Зарубежные центры по подделке российских кредитных билетов (вторая половина XIX в.) // Materialy z VIII Miedzynarodowej Konferencji Numizmatycznej. Pieniadz - capital - praca - wspolne dziedzictwo Europy - Bialorus-Litwa-Lotwa-Polska-RosjaSlowacja-Ukraina. Bialystok-Augustow 18-21 wrzesnia 2008. Warszawa, 2008. S. 193.

10. Много поддельных банкнотов // Галичанин. Ч. 259. вторник, 19 ноября (1 декабря). Львов, 1896. С. 2.

11. Орлик В. М. Державні фінанси Російської імперії першої половини XIX ст.: стан та основні тенденції // Науковий вісник Ізмаїльського державного гуманітарного університету. Вип. 30. Ізмаїл, 2011. С. 96-108.

12. Орлик В. М. До питання методології досліджень проблем економічної історії Російської імперії // Проблеми історії України XIX - початку XX ст. 2011. № 18. С. 59-64.

13. Орлик В. М. До питання фінансової складової війни 1812. Вітчизняна війна 1812 в. i Україна: погляд крізь віки // Тези доповідей. Міжнародна науково-методична конференція, Київ, 5 грудня 2012 р. Відп. ред. В. А. Смолій; Наук. ред. О. П. Реєнт; Упорядн.: О.Ю. Кирієнко, О. М. Машкін, В. В. Шевченко. НАН України. Інститут історії України. Київ: Інститут історії України, 2012.

14. Орлик В. М. Дожовтнева фінансово-правова література як джерело до вивчення проблем фінансової політики уряду Російської імперії кінця XVIII початку XX ст. // Iсторія науки і біографістика. 2010. № 2. URL: http://www.nbuv.gov.ua/e-journals/INB/20102/10_orlyk.pdf

15. Орлик В. М. Єгор Канкрін і фіскальна політика Російської імперії в Правобережній Україні в другій чверті XIX ст. // Спеціальні історичні дисципліни: питання теорії та методики. 2006. № 13. С. 97-110.

16. Орлик В. М. Методологічні аспекти дослідження проблем податкової політики в українських губерніях Російської імперії у першій половині ХІХ ст. // Український історичний журнал. 2008. № 5. С. 187-195.

17. Орлик В. М. Податкова політика Російської імперії в Україні в дореформений період: монографія. Кіровоград: Імекс-ЛТД, 2007. 631 с.

18. Орлик С. В. Розмінні марки та казначейські знаки у грошовому обігу в Україні в період Першої світової війни // Спеціальні історичні дисципліни: питання теорії та методики. Збірка наукових праць. Київ: Інститут історії України, 2015. Число 26-27. C. $141-148$.

19. Орлик С. В. Российские фальшивые кредитные билеты в Галиции в годы Первой мировой войны // Банкаускі Веснік. (2). Минск, 2018. с. 51-54.

20. Орлик С. В. Фінансова політика російського уряду на окупованих територіях Галичини і Буковини в період Першої світової війни (1914-1917рр.): монографія. Біла Церква: Вид. Пшонківський О. В., 2018. 716 с.

21. Орлик С. В., Бойко-Гагарін А. С. Фальшивомонетництво в Україні в роки Першої світової війни // Український нумізматичний щорічник. № 1. Київ, 2017. С. 143164.

22. Орлик С. Вплив фінансових реформ на курс рубля у 60 -х роках XIX століття в Російській імперії // Наукові записки з української історії: зб. наук. статей. Вип. 33. 2013. C. 259-262.

23. Парамонов О. В. Дело Леона Варненке. Документальные свидетельства крупнейшей экономической диверсии, связанной с подделкой в Лондоне российских кредитных билетов во второй половине XIX века // Сборник материалов Первой международной научной конференции (18-19 октября 2018 г., Санкт-Петербург). Деньги в 
российской истории. Вопросы производства, обращения, бытования. Выпуск 1. СанктПетербург, 2018. С. 86-88.

24. Фальшивые банкноты // Дело. Ч. 260. понедельник 18 (30) падолиста. Львов, 1896. C. 3.

25. Фальшивые пятирублевые ассигнации // Киевлянин. № 37. 16 февраля. Киев, 1883. C. 2.

26. Центральний державний історичний архів України, м. Київ (ЦДІАК). Фонд 274. Київське губернське жандармське управління, м. Київ. Опис. 1. Справа 2808. Циркуляр Київського губернатора про затримання осіб збувальників підробок із Англії. Рік. 1911. Арк. 76.

27. Центральний державний історичний архів України, м. Київ (ЦДІАК). Фонд 442. Канцелярія Київського військового, Подільського та Волинського Генерал-Губернатора. Опис 44. Справа 547. По відкладенню Управляючого III відділенням Власної Його Імператорської Величності канцелярії о фальшивих російських кредитних білетах відшуканих із Лондону для розміну в Галичині. Рік 1865. Арк. 1-1 зв.

28. Центральний державний історичний архів України, м. Київ (ЦДІАК). Фонд 285. Фастівське відділення Київського жандармського поліцейського управління залізниць, ст. Фастів Київської губернії. Опис 1. Справа. 956. Розпорядження унтер-офіцерам про недопущення поширення фальшивих кредитних білетів із Англії. Рік. 1911.

29. Archiwum Główne Akt Dawnych w Warszawie (AGAD). Zespol 191. KRSW. Sygnatura 7691. Kurs a falszowanie monet. Vol. II (1825-1826). Str. 14-16.

30. Archiwum Główne Akt Dawnych w Warszawie (AGAD). Zespol 191. KRSW. Sygnatura 7693. Kurs a falszowanie monet. Vol. IV (1829-1832). Str. 95.

31. Archiwum Główne Akt Dawnych w Warszawie (AGAD). Zespol 191. KRSW. Sygnatura 7695. Kurs a falszowanie monet. Vol. VI. (1835-1837). Str. 283-284 odw.

32. Archiwum Państwowe w Warszawie (APW). Zespol 1416/II. KGW. Referat I Tajny. Sygnatura. 3. Секретное дело о распространении польским выходцем Адамом Богушем фальшивых кредитных русских билетов. Rok 1868-1871. Str. 1-2.

33. Kotsur V. P., Boiko-Gagarin A. S. Napoleon russian forged assignations in Naddniprianshchyna (over Dnipro land) // East European historical bulletin. Issue 11. Drohobych, 2019. P. 66-77.

\section{REFERENCES}

1. (1893). Vil'ne priduman novyy rod promysla [Vilnius invented a new kind of fishing]. Nikolaevskiy Vestnik - Nikolaev Herald, 93.3 dekabrya. Nikolaev, 381 [in Russian].

2. Demmeni, M. (1887). Sbornik ukazov po monetnomu $i$ medal'nomu delu v Rossii, pomeshhennyh v Polnom Sobranii Zakonov s 1649 po $1881 \mathrm{~g}$. [A collection of eru decrees on monetary and medal business in Russia, placed in the Complete Collection of Laws from 1649 to 1881.]. Vol. 3. S.-Peterburg: Izdanie Vel. Kn. Georgija Mihajlovicha [in Russian].

3. Derzhavnyi arkhiv Odeskoi oblasti (DAOO) [State Archives of Odessa Oblast (DAOO)]. Fond 1. Upravlinnia Novorosiiskoho ta Bessarabskoho Heneral Hubernatora. Opys 203. Sprava 1. Po vidnoshenniu Nachalnyka Odeskoho mytnoho okruhu, nibyto v pryvezenii iz Londona v Odesu mashyni, shcho nalezhyt yevreiam Iiekhudok Dob Zeidliu ta Yakovu Leibu Livshchytsu, prykhovani falshyvi rosiiski kredytni bilety. Rik 1857. Ark. 1-1 zv. [in Ukrainian].

4. Derzhavnyi arkhiv Odeskoi oblasti (DAOO) [State Archives of Odessa Oblast $(D A O O)]$. Fond 2. Kantseliariia odeskoho hradonchalnyka. Opys 2. Sprava 1111. Pro sposterezhennia nad vvezenniam u Rosiiu falshyvykh kredytnykh biletiv. Rik 1867. Ark. 1-1 zv. [in Ukrainian].

5. Derzhavnyi arkhiv Odeskoi oblasti (DAOO) [State Archives of Odessa Oblast $(D A O O)]$. Fond 2. Kantseliariia odeskoho hradonchalnyka. Opys 2. Sprava 1109. Pro sposterezhennia za turetsko-piddanym yevreiem Marko (vin zhe Mordkhai) Moshkovychem, 
pidozriuvanomu u torhivli falshyvymy kredytnymy biletamy, yakyi dlia tsykh tsilei prybuvaie $\mathrm{v}$ Odesu. Rik 1867. Ark. 3 zv. [in Ukrainian].

6. Derzhavnyi arkhiv Odeskoi oblasti (DAOO) [State Archives of Odessa Oblast $(D A O O)]$. Fond 2. Kantseliariia odeskoho hradonchalnyka. Opys 2. Sprava 1207. Po vidnoshenniu Rosiiskoho heneralnoho konsula u Konstantynopoli, pry yakomu pryslanyi $\mathrm{v}$ Odesu yevrei Yankel Fridman, pidozriuvanyi u zbuti falshyvykh rosiiskykh kredytnykh biletiv i riznykh oblihatsii inshykh derzhav. Rik 1868. Ark. 1-2 zv. [in Ukrainian].

7. Derzhavnyi arkhiv Odeskoi oblasti (DAOO) [State Archives of Odessa Oblast (DAOO)]. Fond 361. Odeskyi popechytelskyi pro tiurmy komitet. Opys 1. Sprava 229. Pro falshyvi kredytni bilety. Rik 1854. Ark. 7 [in Ukrainian].

8. Derzhavnyi arkhiv Ternopilskoi oblasti (DATO) [The State Archives of Ternopil Oblast (DATO)]. Fond 132. Kremenetskyi uiznyi sud. Opys 2. Sprava 684. Sprava pro zvynuvachennia anhliiskoho piddanoho Shmidta u pidrobtsi hroshovykh znakiv. Rik 1858. Ark. 19 [in Ukrainian].

9. Kolobova, I. N. (2008) Zarubezhnye centry po poddelke rossijskih kreditnyh biletov (vtoraja polovina XIX v.). Abstract of Papeers. Pieniadz-capital-praca-wspolne dziedzictwo Europy - Bialorus-Litwa-Lotwa-Polska-Rosja-Slowacja-Ukraina. Bialystok-Augustow 1821 wrzesnia 2008. Warszawa [in Polish].

10. (1986). Mnogo poddel'nykh banknotov [Many counterfeit notes]. Galichanin Galician. Ch. 259. vtornik, 19 noyabrya (1 dekabrya). L'vov, 2 [in Russian].

11. Orlyk, V. M. (2011). Derzhavni finansy Rosiiskoi imperii pershoi polovyny XIX st.: stan ta osnovni tendentsii [The state finances of the Russian Empire in the first half of the XIX century: the condition and main tendencies]. Naukovyi visnyk Izmailskoho derzhavnoho humanitarnoho universytetu, (30), 96-108 [in Ukrainian].

12. Orlyk, V. M. (2011). Do pytannia metodolohii doslidzhen problem ekonomichnoi istorii Rosiiskoi imperii [On the question of the methodology of research on the problems of the economic history ofthe Russian Empire]. Problemy istorii Ukrainy XIX pochatku XX st. - The problems of the History ofUkraine of the 19th and early 20th centuries. 18. 59-64 [in Ukrainian].

13. Orlyk, V. M. (2012). Do pytannia finansovoi skladovoi viiny 1812 [To the question of the financial component of the War of 1812]. Vitchyzniana viina 1812 r. i Ukraina: pohliad kriz viky, 34-35 [in Ukrainian].

14. Orlyk, V. M. (2010). Dozhovtneva finansovo-pravova literatura yak dzherelo do vyvchennia problem finansovoi polityky uriadu Rosiiskoi imperii kintsia XVIII pochatku XX st. [The Prerevolutionary financial and legal literature as a source for studying the problems of the financial policy of the government of the Russian Empire in the late18th early 20th century]. Istoriia nauky $i$ biohrafistyka - History of Science and Biografistica. 2. Retrieved from http://www.nbuv.gov.ua/e-journals/INB/2010-2/10_orlyk.pdf [in Ukrainian].

15. Orlyk, V. M. (2006). Yehor Kankrin i fiskalna polityka Rosiiskoi imperii v Pravoberezhnii Ukraini v druhii chverti XIX st. [Yegor Kankrin and the fiscal policy of the Russian Empire in Right-Bank Ukraine in the second quarter of the nineteenth century]. Spetsialni istorychni dystsypliny:pytannia teorii ta metodyky - Special Historical Disciplines: Theory and Methodology. 13. Nats. akad. nauk Ukrainy, In-t istorii Ukrainy. 97-110 [in Ukrainian].

16. Orlyk, V. M. (2008). Metodolohichni aspekty doslidzhennia problem podatkovoi polityky $\mathrm{v}$ ukrainskykh huberniiakh Rosiiskoi imperii u pershii polovyni XIX st. [The methodological aspects of the study of tax policy issues in the Ukrainian provinces of the Russian Empire in the first half of the XIX century]. Ukrainskyi istorychnyi zhurnal - Ukrainian Historical Journal. 5. 187-195 [in Ukrainian].

17. Orlyk, V. M. (2007). Podatkova polityka Rosiiskoi imperii v Ukraini v doreformenyi period: monohrafiia [Tax policy of the Russian Empire in Ukraine in pre-reform period: a monograph]. Kirovohrad: Imeks-LTD [in Ukrainian]. 
18. Orlyk, S.V. (2015). Rozminni marky ta kaznacheiski znaky u hroshovomu obihu v Ukraini v period Pershoi svitovoi viiny [Exchange Marks and Treasury Marks in Money Circulation in Ukraine during the First World War]. Spetsialni istorychni dystsypliny: pytannia teorii ta metodyky. Zbirka naukovykh prats - Special historical disciplines: questions of theory and methodology. Collection of scientific works, 26-27, 141-148 [in Ukrainian].

19. Orlik, S.V. (2018) Rossijskie fal'shivye kreditnye bilety v Galicii v gody Pervoj mirovoj vojny [Russian fake credit tickets in Galicia during the First World War]. Bankauski Vesnik, 2, 51-54 [in Russian].

20. Orlyk, S.V. (2018) Finansova polityka rosiiskoho uriadu na okupovanykh terytoriiakh Halychyny i Bukovyny v period Pershoi svitovoi viiny (1914-1917 rr.). [Financial Policy of the Russian Government in the Occupied Territories of Galicia and Bukovina during the First World War (1914-1917)]. Bila Tserkva: Vyd. Pshonkivskyi O. V. [in Ukrainian].

21. Orlyk, S. V. \& Boiko-Haharin, A. S. (2017) Falshyvomonetnytstvo v Ukraini v roky Pershoi svitovoi viiny [The money counterfeit during the WWI]. Ukrainskyi numizmatychnyi shchorichnyk. (1). 143-164 [in Ukrainian].

22. Orlyk, S. (2013). Vplyv finansovykh reform na kurs rublia u 60-kh rokakh XIX stolittia $\mathrm{v}$ Rosiiskii imperii [The influence of the financial reforms on the exchange rate of the ruble in 60- th of the XIX c. in Russian Empire]. Naukovi zapysky z ukrainskoi istorii Scientific notes on Ukrainian history, 33, 259-262 [in Ukrainian].

23. Paramonov, O. V. (2018). Delo Leona Varnenke. Dokumental'nye svidetel'stva krupnejshej jekonomicheskoj diversii, svjazannoj s poddelkoj v Londone rossijskih kreditnyh biletov vo vtoroj polovine XIX veka [The Leon Varnenke case. Documentary evidence of the largest economic sabotage related to counterfeiting of Russian credit bills in London in the second half of the 19th century.]. Abstract of Papeers. Den'gi v rossijskoj istorii. Voprosy proizvodstva, obrashhenija, bytovanija, 1, 86-88 [in Russian].

24. (1896). Fal'shivye banknoty [Counterfeit notes]. Delo-The case. Ch. 260. ponedel'nik 18 (30) padolista. L'vov, 3 [in Russian].

25. (1883). Fal'shivye pyatirublevye assignatsii [False five-ruble appropriations]. Kievlyanin - Kievite, 37. 16 fevralya. Kiev, 2 [in Russian].

26. Tsentralnyi derzhavnyi istorychnyi arkhiv Ukrainy, m. Kyiv (TsDIAK) [Central State Historical Archives of Ukraine, Kyiv (CDAC)]. Fond 274. Kyivske hubernske zhandarmske upravlinnia, m. Kyiv. Opys. 1. Sprava 2808. Tsyrkuliar Kyivskoho hubernatora pro zatrymannia osib zbuvalnykiv pidrobok iz Anhlii. Rik. 1911. Ark. 76 [in Ukrainian].

27. Tsentralnyi derzhavnyi istorychnyi arkhiv Ukrainy, m. Kyiv (TsDIAK) [Central State Historical Archives of Ukraine, Kyiv (CDAC)]. Fond 442. Kantseliariia Kyivskoho viiskovoho, Podilskoho ta Volynskoho Heneral-Hubernatora. Opys 44. Sprava 547. Po vidkladenniu Upravliaiuchoho III viddilenniam Vlasnoi Yoho Imperatorskoi Velychnosti kantseliarii o falshyvykh rosiiskykh kredytnykh biletakh vidshukanykh iz Londonu dlia rozminu v Halychyni. Rik 1865. Ark. 1-1 zv. [in Ukrainian].

28. Tsentralnyi derzhavnyi istorychnyi arkhiv Ukrainy, m. Kyiv (TsDIAK) [Central State Historical Archives of Ukraine, Kyiv (CDAC)]. Fond 285. Fastivske viddilennia Kyivskoho zhandarmskoho politseiskoho upravlinnia zaliznyts, st. Fastiv Kyivskoi hubernii. Opys 1. Sprava 956. Rozporiadzhennia unter-ofitseram pro nedopushchennia poshyrennia falshyvykh kredytnykh biletiv iz Anhlii. Rik. 1911 [in Ukrainian].

29. Archiwum Gtówne Akt Dawnych w Warszawie (AGAD) [Central Archives of Historical Records in Warsaw (AGAD)]. Zespol 191. KRSW. Sygnatura 7691. Kurs a falszowanie monet. Vol. II (1825-1826). Str. 14-16 [in Polish].

30. Archiwum Główne Akt Dawnych w Warszawie (AGAD) [Central Archives of Historical Records in Warsaw (AGAD)]. Zespol 191. KRSW. Sygnatura 7693. Kurs a falszowanie monet. Vol. IV (1829-1832). Str. 95 [in Polish]. 
31. Archiwum Główne Akt Dawnych w Warszawie (AGAD) [Central Archives of Historical Records in Warsaw (AGAD)]. Zespol 191. KRSW. Sygnatura 7695. Kurs a falszowanie monet. Vol. VI. (1835-1837). Str. 283-284 odw. [in Polish].

32. Archiwum Państwowe $w$ Warszawie (APW) [The State Archives in Warsaw (APW)]. Zespol 1416/II. KGW. Referat I Tajny. Sygnatura. 3. Секретное дело о распространении польским выходцем Адамом Богушем фальшивых кредитных русских билетов. Rok 18681871. Str. 1-2[in Polish].

33. Kotsur, V. \& Boiko-Gagarin, A. (2019) Napoleon russian forged assignations in Naddniprianshchyna (over Dnipro land). East European historical bulletin. (11). Drohobych. pp. 66-77 [in English].

Одержано 20.05.2019.

УДК 930.2(092)(477.5) «1816/2019»

\author{
Вуйко Богдан, \\ аспірант кафедри історії та культури \\ України \\ mega-bogdan59@ukr.net \\ http://orcid.org/0000-0002-9296-6042 \\ Державний вищий навчальний заклад \\ «Переяслав-Хмельницький державний \\ педагогічний університет імені Григорія \\ Сковороди», \\ вул. Сухомлинського, 30, \\ м. Переяслав-Хмельницький, Київська обл., \\ Україна, 08401
}

\section{DOI https://doi.org/10.31470/2415-3567- 2019-46-218-225}

\section{Vuiko Bogdan,}

a post graduate student of Department of

History and Culture of Ukraine

mega-bogdan59@ukr.net

http://orcid.org/0000-0002-9296-6042

Pereiaslav-Khmelnytsky Hryhorii Skovoroda

State Pedagogical University,

30, Sukhomlynsky Str.,

Pereiaslav-Khmelnytskyi, Kyiv region,

Ukraine, 08401

\section{ІСТОРІОГРАФІЧНІ РЕФЛЕКСІЇ ЩОДО УЧАСТІ М.Г. РЕПНІНА (ВОЛКОНСЬКОГО) В НАПИСАННІ «ИСТОРИИ МАЛОЙ РОСИИ» Д.М. БАНТИШ-КАМЕНСЬКИМ}

У статті здійснено аналіз історіографії щзодо вагомої ролі М.Г. Рєпніна (Волконського) у підготовиі, написанні та оприлюднені першої синтетичної праці «Истории Малой Росии» Д.М. Бантиш-Каменським. Встановлено, щэо дослідники в ХІХна початку XXI cm. розглядали внесок М.Г. Рєпніна в справу підготовки та написання історії України з різних наукових позицій. Д.І. Дорошенко вважав, щзо написання історії Украйни є справою політичною. Показано, щчо на сучасному етапі украйнські науковці віддаючи належне постаті М.Г. Репніна та його активній участі в суспільнополітичному житті Малоросії того часу, вважають, щзо ніякого політичного підтексту у справі підготовки історії України, і ї̈ змісті не було, за задумом князя, підготовка праці такого спрямування мала на меті довести, щз малоросійська шляхта мала такі ж права на дворянство, а звідси і на чини, як і великоросійське дворянство. Акцентовано увагу на позииії, що М.Г. Рєпнін не лише здійснив намір багатьох культурних діячів того часу, замовивши написання систематичної праџі з історії України, але згуртував їх навколо себе, створивши таким чином своєрідний літературно-просвітницький гурток, характер 